\title{
AKTIVITAS BERMAIN PESERTA DIDIK DITINJAU DARI ASPEK PSIKOLOGIS SISWA SEKOLAH DASAR NEGERI 09 TELUK BAKUNG KECAMATAN BAYANG KABUPATEN PESISIR SELATAN \\ Titit Indriani ${ }^{1}$, Gusril ${ }^{2}$. Andri Gemaini \\ Jurusan Kesehatan dan Rekreasi, Universitas Negeri Padang, \\ Padang, Indonesia \\ tititindriani02@gmail.com
}

\begin{abstract}
The problem in this research is the unknown playing activities of SDN 09 Teluk Bakung students in the Bayang District regarding psychological aspects. The purpose of this study was to determine the level of play activity of students in terms of the psychological aspects of SDN 09 Teluk Bakung Bayang District.

This type of research is descriptive which aims to describe systematically, factually, and accurately about the facts and the nature of a particular population or try to describe the phenomenon in detail. When the study was conducted on February 13, 2020. The population in this study amounted to 122 people. Sampling was carried out by Porpusive Sampling technique, with certain considerations of 50 people. The instrument used in this study is a Likert scale.

The results of this study obtained the highest value of 137 points and the lowest value was 76 points. Furthermore, the mean value obtained 101 (101) was obtained. The results of this study showed the students' playing activities in terms of psychological aspects of elementary school students at SDN
\end{abstract}

\section{Keywords: play activity, psychological aspects}

\section{Abstrak}

Masalah dalam penelitian ini adalah belum diketahuinya aktivitas bermain siswa SDN 09 Teluk Bakung Kecamatan Bayang mengenai aspek psikologis. Tujuan penelitian ini adalah untuk mengetahui tingkat aktivitas bermain peserta didik ditinjau dari aspek psikologis SDN 09 Teluk Bakung Kecamatan Bayang.

Jenis penelitian ini adalah Deskriptif yang bertujuan untuk mendeskripsikan secara sistematis, factual, dan akurat mengenai fakta-fakta dan sifat populasi tertentu atau mencoba menggambarkan fenomena secara detail. Waktu penelitian dilakukan pada 13 februari 2020. Populasi dalam penelitian ini berjumlah 122 orang. Penarikan sampel dilakukan dengan teknik Porpusive Sampling, dengan pertimbangan tertentu yaitu 50 orang. Instrument yang digunakan dalam penelitian ini adalah skala likert.

Hasil penelitian ini diperoleh nilai tertinggi 137 poin dan nilai terendah adalah 76 poin. Selanjutnya diperoleh nilai rata-rata hitung (mean) 101. Hasil penelitian ini menunjukan aktifitas bermain peserta didik ditinjau dari aspek psikologis siswa sekolah dasar SDN 09 Teluk Bakung Kecamatan Bayang 86,00\% tergolong baik.

\section{Kata kunci : aktivitas bermain, aspek psikologis}

Pendidikan merupakan salah satu faktor yang sangat penting dalam ilmu pengetahuan dan teknologi saat sekarang ini. Oleh sebab itu maka pendidikan tidak dapat terpisahkan dari kehidupan manusia. Dalam Undang-Undang Dasar Republik Indonesia 1945 (UUD RI 1945) dijelaskan juga bahwa setiap orang berhak mendapatkan pendidikan, hal itu diatur dalam pasal 31 ayat 1-5 Dalam UUD RI 1945 Dalam pasal 31 
E-ISSN2655-2515

P-ISSN2655-1802

ayat 2 dan 3 dijelaskan bahwa bagi siapa saja warga negara berhak mendapatkan pendidikan, dan pemerintah wajib membiayainya, hal itu bertujuan untuk mencapai tujuan bangsa yaitu untuk mencerdaskan kehidupan bangsa.

Pendidikan sekolah ditekankan kepada bentuk pendidikan sekolah dasar (SD) yang terdapat dijalur pendidikan sekolah. SD adalah suatu lembaga pendidikan sekolah bagi anak yang berusia 7-12 tahun. Sebagai mana di jelaskan dalam Undang-undang tentang Pendidikan Nasional No. 20 tahun 2003: "Pendidikan adalah usaha sadar dan terencana untuk mewujudkan suasana belajar dan proses pembelajaran agar peserta didik secara aktif mengembangkan potensi dirinya untuk memiliki kekuatan spiritualkeagamaan, pengendalian diri, kepribadian, kecerdasan, dan

akhlak mulia, serta keterampilan yang diperlukan dirinya, masyarakat, bangsa dan negara".

Pendidikan nasional berfungsi mengembangkan kemampuan dan watak serta peradaban bangsa yamg bermartabat dalam rangka mencerdaskan kehidupan bangsa, bertujuan untuk berkembangnya potensi peserta didik agar menjadi manusia yang beriman dan bertaqwa kepada tuhan yang maha esa,berakhlak mulia, sehat, beriman, cakap, kreatif, mandiri, dan menjadi warga negara yang demokratif secara bertanggung jawab (Sisdiknas,2003:6).

Berdasarkan kutipan diatas jelaslah bagi kita bahwa pendidikan tersebut sangat mempunyai peranan penting untuk mewujudkan watak seseorang yang akhirnya menjadi cerdas, yang beriman dan bertaqwa kepada tuhan yang maha esa, berakhlak, mulia, sehat jasmani, dan rohani dapat dilakukan dengan berbagai cara baik di lingkungan tempat tinggal maupun sekolah.

Psikologi sering diterjemahkan menjadi ilmu jiwa yakni, dari kata psyche yang berarti : jiwa, roh dan logos yang berarti: ilmu. Namun terjemahan tersebut kurang tepat, karena bertitik-tolak dari pandangan dualisme manusia, yang menganggap bahwa manusia itu sendiri terdiri dari dua bagian jasmani dan rohani. Menurut Ngalim Purwanto (2007) psikologi adalah ilmu yang ingin mempelajari manusia. Manusia sebagai suatu kesatuan yang bulat antara jasmani dan rohani.

Menurut Penney Upton (2012:2) psikologi perkembangan adalah studi ilmiah tentang perubahan-perubahan pikiran dan perilaku yang berkaitan dengan usia. Yang diyakini bahwa perkembangan seluruh keterampilan dan kemampuan kita selesai dimasa kanak kanak. Namun perkembangan adalah proses sepanjang hidup perubahan tidak henti ketika kita memasuki masa dewasa. Sedangkan aspek-aspek yaitu sebuah kategori grametikal verbal atau lebih singkatnya aspek adalah seperti hal-hal atau unsur-unsur yang menunjukkan lama dan jenis perbuatan. 
P-ISSN2655-1802

Berdasarkan pendapat ahli diatas aspek psikologi adalah ilmu yang mempelajari tentang hal-hal atau unsur jenis perbuatan perubahan pikiran manusia dan tingkah lakunya yang kelihatan dari cara berbicara, berjalan, berfikir, mengambil keputusan, cara bereaksi terhadap lingkungan yang berkaitan dengan usia.

Menurut Patmonodewo dalam Anton Komaini (2018 :76) Konsep aktivitas bermain adalah sebagai suatu kegiatan bermain dimana anak mendapat kesempatan melakukan berbagai pilihan permainan dengan ataupun tahap alat, serta mereka dapat memilih bagaimana menggunakan alat-alat tersebut. Lebih lanjut Semiawan (2002:20) mengemukakan bahwa: bagi anak, aktivitas bermain adalah suatu kegiatan yang serius, namun mengasyikan, melalui aktivitas bermain, berbagai pekerjaan terwujud. Bermaian adalah aktivitas yang dipilih sendiri oleh anak karena menyenangkana bukan karena memperoleh hadiah atau pujian, bermain juga salah satu alat utama yang menjadi latihan untuk pertumbuhannya, bila anak bermain secara bebas sesuai kemampuan maupun sesuai kecepatannya sendiri, maka ia melatih kemampuannya.

Berdasarkan beberapa definisi diatas, disimpulkan bahwa aktivitas bermain adalah segala kegiatan spontan yang menyenangkan dan memiliki nilai positif bagi anak, tidak memiliki tujuan ekstrinsik, namun motivasinya lebih bersifat instrinsik, melibatkan peran serta aktif anak baik memakai alat ataupun tanpa alat, tanpa memikirkan hasil akhir yang dilakukan tanpa paksaan orang lain, dan tidak mengharapkan imbalan maupun pujian.

Menurut Gusril (2009:59) ada beberapa Sifat sosial psikologis pada usia 10-12 tahun; a) senang aktivitas yang aktif, b) minat melakukan olahraga kompetitif meningkat, c) minat terhadap permainan yang teroganisir meningkat, d) rasa kebanggan terhadap keterampilan yang dikuasai tinggi dan cenderung berusaha untuk memperoleh kebanggaan, e) selalu berusaha untuk menarik perhatian orang dewasa tentang apa yang dilakukan, f) mempercayai orang dewasa dan selalu berusaha meminta persetujuan orang dewasa tentang apa yang telah dilakukan, h) cepat puas bila mencapai sesuatu dan sangat kecewa jika mengalami kegagalan, i) cenderung memuja kepahlawanan, kondisi emosinya belum stabil, mudah gembira dan mudah sedih, j) mulai memahami arti waktu dan ingin mencapai sesuatu pada waktunya.

Setiap individu dikatakan sebagai peserta didik apabila ia telah memasuki usia sekolah. Usia 4 sampai 6 tahun, di Taman Kanak-kanak, usia 6 sampai 12 tahun di Sekolah Dasar, usia 13-16 tahun di SMP dan usia 16-19 SLTA. Jadi peserta didik adalah anak yang tergolong dan tercatat sebagai siswa didalam satuan pendidikan. Adapun Faktofaktor yang mempengaruhi perkembangan psikolagi anak yaitu factor internal dan eksternal, faktor internalnya adalah faktor yang berasal dari dalam diri anak itu sendiri yang biasanya bawaan gen atau keturunannya. Kemudian faktor eksternal berasal dari 
luar anak tersebut, yang biasanya pengaruh dari lingkungan terkecilnya, yakni keluarga, teman, tetangga, dan sampai berpengaruh dari berbagai media audiovisual seperti TV, VCD, dan HP atau media cetak seperti Majalah, Koran.

Seiring dengan adanya kemajuan teknologi pada abad modern ini, menawarkan banyak sekali kemudahan dalam berbagai aktifitas manusia. Diantaranya adalah kemajuan informasi dan komunikasi yang bersifat global. Orang-orang akan sangat mudah untuk mendapatkan informasi, tanpa harus memperhitungkan batas wilayah dan negara. Selain di tandai semakin mudahnya mendapatkan informasi dari belahan bumi lain, kemajuan teknologi juga dimanfaatkan sebagai media hiburan. Saat ini, banyak orangorang, terutama kalangan anak-anak yang memanfaatkan teknologi ini untuk hiburan, salah satunya bermain games online.

Jika kita kembali pada beberapa tahun kebelakang. Jarang sekali orang dapat bermain Games Online. Dikarenakan masa itu internet hanya tersedia di kota-kota besar. Selain itu jumlah manusia yang memiliki komputer dan handphone sangat terbatas. Hanya orang-orang golongan kelas atas dan kalangan bisnis yang memiliki fasilitas tersebut. Sedangkan, sekarang hampir semua orang menggenggam Smartphone di tangan, tidak terkecuali anak-anak. Dengan adanya fasilitas komputer dan smartphone itulah anakanak senang bermain games online di internet game offline. namun bukan berarti kita boleh melupakan efek negatif dari Games Online tersebut. Salah satu efek negatif dari permainan tersebut erat kaitannya dengan relasi sosial.

Kemudian pada zaman dahulu, anak-anak dalam bermain kelompok, sehingga terjalin hubungan sosial yang kuat. Seperti anak-anak akan bermain gasing dan layangan. Permainan tersebut tentu saja tidak menyenangkan jika hanya dimainkan sendiri. Sehingga dari kecil anak-anak sudah terbiasa melakukan hubungan sosial. Selain diajarkan peka dalam hubungan sosial, permainan tersebut juga meningkatkan kreatifitas anak dalam menciptakan sesuatu.

Salah satu bukti nyatanya adalah, jika akan bermain gasing anak-anak biasanya membuat gasing tersebut secara independent. Tidak jarang di perdesaan anak-anak akan mengambil kayu sendiri dari hutan. Begitu juga dengan pembuatan layang-layang. Sehingga anak-anak yang telah terbiasa melakukan itu secara mandiri, mereka secara tidak lansung telah belajar sesuatu hal yang besar yaitu mereka diajarkan untuk lebih menghargai suatu proses.

Namun di zaman modern ini, permainan tradisional itu berlahan mulai di tinggalkan. Anak-anak akan cenderung untuk memilih permainan instant, yang tentunya lebih mudah. Jika mereka memiliki komputer dan smartphone, maka mereka cukup mendownload games yang menjamur di internet. Setelah itu permainan tersebut sudah 
dapat dimainkan.

Masa usia sekolah dasar sebagai masa kanak-kanak yang berlangsung dari usia enam tahun hingga kira-kira usia sebelas tahun atau dua belas tahun karakteristik utama siswa sekolah dasar adalah mereka menampilkan perbedaan-perbedaan individual dalam banyak segi dan bidang, diantaranya perbedaan dalam intelegensi, kemampuan dalam kognitif dan bahasa, perkembangan kepribadian dan perkembangan fisik anak. Menurut Erikson perkembangan psikologi pada usia enam sampai puberitas, anak mulai memasuki dunia pengetahuan dan dunia kerja yang luas. Peristiwa penting pada tahap anak mulai masuk sekolah dimulai dihadapkan dengan teknologi masyarakat, disamping itu proses belajar mereka tidak hanya terjadi disekolah. Sedangkan menurut Thombang (1984) anak sekolah dasar merupakan individu yang sedang berkembang, barang kali tidak perlu lagi diragukan keberaniannya. Setiap anak sekolah dasar sedang berada dalam perubahan fisik maupun mental mengarah yang lebih baik tingkah laku mereka dalam menghadapi lingkungan sosial maupun non sosial meningkat anak memiliki kemampuan tentang rasa dan kerja sama yang lebih tinggi bahkan ada diantara mereka yang menampakkan tingkah laku mendekati tingkah laku anak remaja permulaan.

Berdasarkan uraian di atas, siswa sekolah dasar berada pada tahap operasional kongkrit, pada tahap ini anak mengembangkan logis masih sangat terikat pada fakta fakta perseptual, artinya anak mampu berfikir logis, tetapi masih terbatas objek-objek kongkrit dan mampu melakukan konservasi. Bertitik tolak pada perkembangan intelektual dan psikolosiosial siswa sekolah dasar, hal ini menunjukkan bahwa mereka mempunyai karakteristik sendiri, dimana dalam proses berfikirnya mereka belum dapat dipisahkan dari dunia kongkrit atau hal hal yang faktual sedangkan perkembangan psikologi anak usia sekolah dasar masih berpijak pada prinsip yang sama dimana tidak dapat dipisahkan dari hal-hal yang dapat diamati, karena sudah diharapkan pada dunia pengetahuan.

Setelah peneliti melakukan observasi di SD 09 Teluk bakung Kecamatan Bayang terlihat pada aktivitas bermain anak saat sekarang ini cukup memperihatinkan yang dipengaruhi dengan berbagai permainan teknologi, gadjet dari android permainan game online dan game offline yang sangat memukau sehingga lupa waktu, mereka menghabiskan waktu bermain game online di warnet, mereka juga menghabiskan waktu bermain PS dan lebih parah lagi mereka minta dibelikan gadget yang harganya mahal dan lupa bahwa mereka masih anak-anak yang perlu belajar, mengasah otak, melatih mental dan spiritual.

Permainan gadjet pada anak saat sekarang, juga dapat memberikan pengaruh yang negatif terhadap anak tersebut, yang mana tidak ada lagi keluar keringat, tidak ada lagi terasah otak anak, tidak ada lagi permainan strategi yang menggunakan fisik, dan tidak 
E-ISSN2655-2515

P-ISSN2655-1802

ada lagi kegembiraan bersama teman-teman sekampungnya. dan sangat disayangkan bila masa kecil mereka yang penuh kegembiraan terlewati.

Faktor lainnya kurangnya lokasi bermain anak-anak yang layak sehingga membuat anak-anak menjadi malas melakukan aktivitas bermain dan tidak ingin bergerak kemudian sarana dan prasarana yang kurang memadai, sehingga dalam melakukan aktivitas bermain anak cepat bosan serta kurang bersemangat. Beberapa faktor yang mempengaruhi aktivitas bermain anak seperti lingkungan sosial yang kurang baik dan lebih memilih melakukan aktivitas didalam rumahnya, pola asuh orang tua kepada anaknya yang tidak memperhatikan dan tidak acuh dengan apa yang dilakukan anaknya membiarkan anak bermain sampai lupa waktu untuk belajar, kesurau dan lainnya. status ekonomi orang tua yang pendapatan mereka lebih dominan pekerjaan mereka petani dan sebagiannya lagi tinggi perkejaan mereka pengusaha dan pegawai lainnya, juga pemberian gizi orang tua yang kurang baik kepada anaknya.

Masalah lainnya ketika guru penjas memberikan suatu permainan kepada anak disekolah $45 \%$ anak bermain kurang aktif dalam melakukan aktivitas bermain dikarenakan anak-anak tersebut tidak tertarik, dengan permainannya sehingga malas bergerak dan $30 \%$ anak lebih memilih untuk diam dan hanya menonton saja, $25 \%$ anak aktif pada saat melakukan aktivitas bermain tersebut sebab anak lebih suka bergerak, histeris dan bersemangat saat akan melakukan aktivitas bermain.

Dari permasalahan yang telah diuraikan diatas, maka penulis tertarik untuk meneliti "aktivitas bermain peserta didik di tinjau dari aspek psikologis SDN 09 Teluk Bakung Kecamatan Bayang Kabupaten Pesisir Selatan". Melalui penelitian ini diharapkan akan diperoleh jawaban dari permasalahan yang terjadi dilapangan.

\section{Metode}

Penelitian ini adalah tergolong penelitian deskriptif menurut A.Muri (2005:83) penelitian deskriptif adalah jenis penelitian yang bertujuan untuk mendeskripsikan secara sistematis, faktual dan akurat mengenai fakta-fakta dan sifat populasi tertentu atau mencoba menggambarkan fenomena secara detail. maka tujuan penelitian ini untuk menggambarkan data sebagaimana mestinya. 


\section{Hasil Penelitian}

\section{A. HasilPenelitian \\ 1. Aktivitas Bermain}

Data pertanyaan tertutup dikumpulkan melalui angket yang disebarkan kepada 50 orang peserta didik yang menjadi sampel dalam penelitian. Dari hasil pengisian angket tersebut terlihat skor pertanyaan tertutup tertinggi (maksimal) yang dapat dicapai oleh peserta didik adalah 137 poin dan nilai terendah (minimal) adalah 76 poin. Selanjutnya diperoleh nilai rata-rata hitung (mean) 101 standar deviasi (SD) 13,2 median 99,5 modus 96. Distribusi hasil data pengukuran angket dengan pertanyaan tertutup dapat dilihat pada tabel distribusi frekuensi dibawah.

Tebel 6. Distribusi frekuensi pertanyaan tertutup tentang aktivitas bermain peserta didik di sekolah dasar negeri 09 teluk bakung

\begin{tabular}{|c|c|c|c|c|}
\hline NO & Kelas Interval & $\begin{array}{c}\text { Frekuensi } \\
\text { Komulatif }\end{array}$ & $\begin{array}{c}\text { Frekuensi } \\
\text { Relatif }\end{array}$ & Keterangan \\
\hline 1 & $76-100 \%$ & 4 & $8,00 \%$ & Sangat Baik \\
\hline 2 & $51-75 \%$ & 43 & $86,00 \%$ & Baik \\
\hline 3 & $26-50 \%$ & 3 & $6,00 \%$ & Kurang Baik \\
\hline 4 & $0-25 \%$ & 0 & $0,00 \%$ & Tidak Baik \\
\hline 5 & TOTAL & 50 & $100 \%$ & \\
\hline
\end{tabular}

Tabel diatas menunjukkan bahwa dari 50 orang peserta didik yang menjadi sampel dalam penelitian ini terdapat sebanyak 4 orang (8,00\%) pada klasifikasi $76-100 \%$ dengan kategori sangat baik, pada klasifikasi $51-75 \%$ terdapat sebanyak 43 orang ( $86,00 \%)$ dengan kategori baik, pada klasikifikasi $26-50 \%$ terdapat 3 orang $(6,00 \%)$ dengan kategori kurang bak, pada kalsifikasi 0 -25\% tidak terdapat seorangpun peserta didik $(0,00 \%)$. untuk lebih jelasnya dapat dilihat pada histrogram berikut .

Histogram 1. Pertanyaan Tertutup tentang Aktivitas Bermain Peserta Didik di Sekolah Dasar Negeri 09 Teluk Bakung

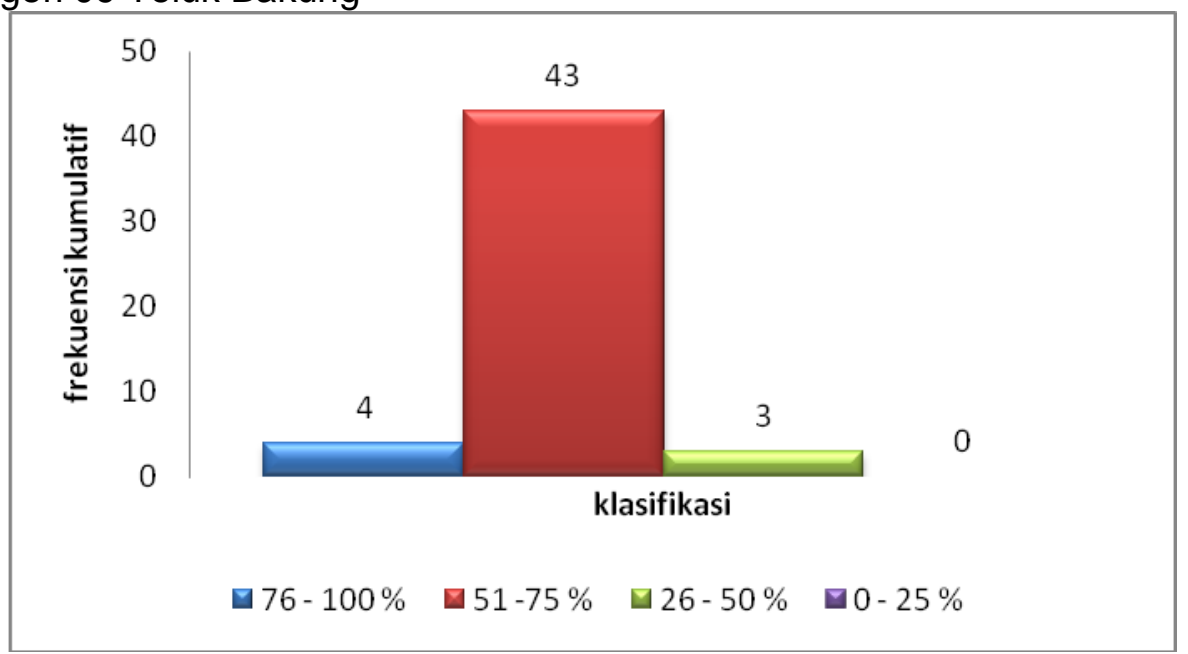

Tabel 7. Distribusi Kelas Interval frekuensi aktivitas bermain

\begin{tabular}{|c|c|c|c|}
\hline No & $\begin{array}{c}\text { Kelas } \\
\text { Interval }\end{array}$ & Frekuensi Absolut & $\begin{array}{c}\text { Frekuensi Relatif } \\
\%\end{array}$ \\
\hline 1 & $76-82$ & 4 & $8 \%$ \\
\hline 2 & $83-89$ & 5 & $10 \%$ \\
\hline
\end{tabular}




\begin{tabular}{|c|c|c|c|}
3 & $90-96$ & 12 & $24 \%$ \\
\hline 4 & $97-103$ & 11 & $22 \%$ \\
\hline 5 & $104-110$ & 6 & $12 \%$ \\
\hline 6 & $111-117$ & 5 & $10 \%$ \\
\hline 7 & $118-124$ & 5 & $10 \%$ \\
\hline 8 & $125-131$ & 1 & $2 \%$ \\
\hline 9 & $132-138$ & 1 & $2 \%$ \\
\hline & Total & 50 & $100 \%$ \\
\hline
\end{tabular}

Berdasarkan analisis tabel diatas, bahwa pada kelas interval 76-82 ada 4 orang dengan pesentase $8 \%$, selanjutnya pada kelas interval 83-89 ada 5 orang dengan persentase $10 \%$, selanjutnya pada kelas interval $90-96$ ada 12 orang dengan pesentase $24 \%$, pada kelas interval 97-103 ada 11 orang dengan persentase $22 \%$, selanjutnya pada kelas interval 104-110 ada 6 orang dengan persentase $12 \%$, selanjutnya 111-117 ada 5 orang dengan persentase $10 \%$, selanjutnya pada pesentase 118-124 ada 5 orang dengan persentase $10 \%$, selanjutnya pada kelas interval 125-131 ada 1 orang dengan persentase $2 \%$, selanjutnya kelas interval $132-138$ ada 1 orang dengan persentase $2 \%$. Untuk lebih jelas dapat dilihat pada histogram dibawah ini :

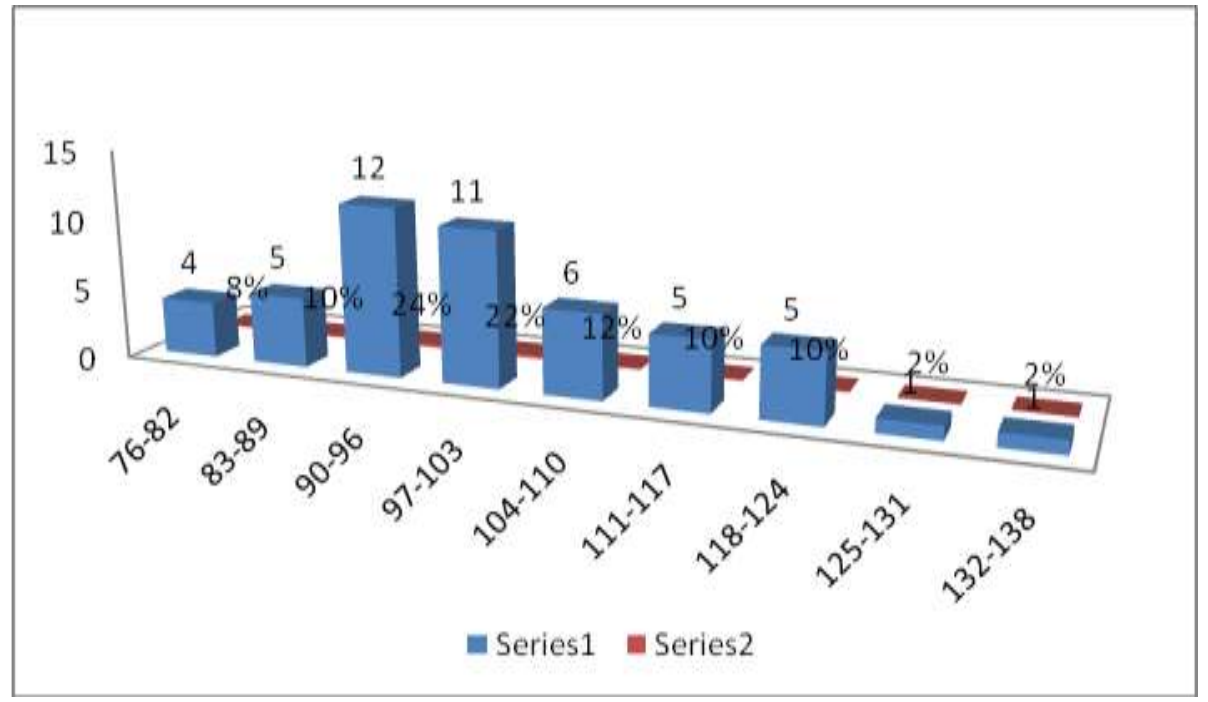

Histogram 2. Aktivitas bermain

\section{Pertanyaan Terbuka}

a. Jumlah Permainan yang Dilakukan Anak-Anak Diluar Waktu Sekolah

Dari pertanyaan terbuka yang telah diwawancara kepada 50 orang peserta didik dari hasil analisis data terlihat jumlah permainan yang dilakukan anak-anak diluar waktu sekolah rata-rata tanpa membedakan jenis kelamin memilih 3 permainan setiap hari dengan persentase $32 \%$. Jenis permainan yang dilakukan diluar waktu sekolah yaitu kejar-kejaran,petak umpat bola kasti, main tali, batu tujuh,sepak tekong. Dapat dilihat pada tabel dibawah ini. 
Tabel 6. Jumlah Permainan yang Dilakukan Anak-Anak Diluar Waktu Sekolah

\begin{tabular}{|c|c|c|c|c|c|c|c|}
\hline \multirow{2}{*}{ No } & \multirow{2}{*}{$\begin{array}{c}\text { Jumlah } \\
\text { mainapern }\end{array}$} & $\begin{array}{c}\text { Laki- } \\
\text { laki }\end{array}$ & $\mathbf{\%}$ & Perempuan & \% & \multirow{2}{*}{ Jumlah } & \multirow{2}{*}{ J } \\
\hline $\mathbf{1}$ & 10 & 0 & $0 \%$ & 0 & $0 \%$ & 0 & $0 \%$ \\
\hline $\mathbf{2}$ & 8 & 0 & $0 \%$ & 0 & $0 \%$ & 0 & $0 \%$ \\
\hline $\mathbf{3}$ & 7 & 0 & $0 \%$ & 0 & $0 \%$ & 0 & $0 \%$ \\
\hline $\mathbf{4}$ & 6 & 2 & $7,14 \%$ & 2 & $9,09 \%$ & 4 & $8 \%$ \\
\hline $\mathbf{5}$ & 5 & 2 & $7,14 \%$ & 0 & $0,00 \%$ & 2 & $4 \%$ \\
\hline $\mathbf{6}$ & 4 & 6 & $21,43 \%$ & 2 & $9,09 \%$ & 8 & $16 \%$ \\
\hline $\mathbf{7}$ & 3 & 10 & $35,71 \%$ & 6 & $27,27 \%$ & 16 & $32 \%$ \\
\hline $\mathbf{8}$ & 2 & 5 & $17,86 \%$ & 6 & $27,27 \%$ & 11 & $22 \%$ \\
\hline $\mathbf{9}$ & 1 & 3 & $10,71 \%$ & 6 & $27,27 \%$ & 9 & $18 \%$ \\
\hline Total & 46 & 28 & $100 \%$ & 22 & $100 \%$ & 50 & $100 \%$ \\
\hline
\end{tabular}

Berdasarkan tabel diatas tidak ada seorang pun (0\%) anak laki-laki maupun anak perempuan yang melakukan permainan sebanyak 10 buah permainan diluar waktu sekolah, begitu juga dengan jumlah permainan sebanyak 8 dan 7 permainan. Terdapat sebanyak 2 orang anak laki-laki (7,14\%) dan sebanyak 2 orang (9,09\%) anak perempuan yang melakukan permainan sebanyak 6 buah permainan diluar waktu sekolah dengan jumlah sebanyak 4 orang (8\%). Terdapat 2 orang anak laki-laki $(7,14 \%)$ dan tidak terdapat satu orang pun $(0 \%)$ anak perempuan yang melakukan permainan sebanyak 5 buah permainan diluar waktu sekolah dengan jumlah sebanyak 2 orang (8\%). Terdapat 6 orang anak laki-laki $(21,43 \%)$ dan 2 orang anak perempuan $(9,09 \%)$ yang melakukan permainan sebanyak 4 buah permainan diluar waktu sekolah dengan jumlah sebanyak 8 orang (16\%). Terdapat 10 orang anak laki-laki $(35,71 \%)$ dan 6 orang anak perempuan $(27,27 \%)$ yang melakukan permainan sebanyak 3 buah permainan diluar waktu sekolah dengan jumlah sebanyak 16 orang (32\%). Terdapat 5 orang anak laki-laki $(17,86 \%)$ dan 6 orang anak perempuan $(27,27 \%)$ yang melakukan permainan sebanyak 2 buah permainan diluar waktu sekolah dengan jumlah sebanyak 11 orang (22\%). Terdapat 3 orang anak laki-laki $(10,71 \%)$ dan 6 orang anak perempuan $(27,27 \%)$ yang melakukan permainan sebanyak 1 buah permainan diluar waktu sekolah dengan jumlah 9 orang (18\%).

b. Jumlah Permainan yang Dilakukan Anak-anak di Sekolah Setiap Hari

Dari pertanyaan terbuka yang telah diwawancara kepada 50 orang peserta didik terdapat hasil analisis data dilihat bahawa jumlah permainan yang dilakukan anak-anak disekolah rata-rata tanpa membedakan jenis kelamin memilih 1 permainan setiap hari dengan persentase $34 \%$. Jenis permainan yang dilakukan disekolah setiap hari yaitu cik mancik, pacu lari, sepak bola, bola kasti, main en, kejar-kejaran, dan kelereang. Untuk lebih jelas dapat dilihat pada tabel dibawah.

Tabel 7. Jumlah Permainan yang Dilakukan Anak-anak di Sekolah Setiap Hari

\begin{tabular}{|c|c|c|c|c|c|c|c|}
\hline \multirow[b]{2}{*}{ No } & \multirow[b]{2}{*}{$\begin{array}{c}\text { Jumlah } \\
\text { Permainan }\end{array}$} & \multicolumn{4}{|c|}{ Jenis Kelamin } & \multirow[b]{2}{*}{ Jumlah } & \multirow[b]{2}{*}{$\%$} \\
\hline & & $\begin{array}{l}\text { Laki- } \\
\text { Laki }\end{array}$ & $\%$ & Perempuan & $\%$ & & \\
\hline 1 & 8 & 0 & $0 \%$ & 0 & $0,00 \%$ & 0 & $0 \%$ \\
\hline 2 & 7 & 0 & $0 \%$ & 0 & $0,00 \%$ & 0 & $0 \%$ \\
\hline 3 & 6 & 1 & $3,57 \%$ & 1 & $4,55 \%$ & 2 & $4 \%$ \\
\hline 4 & 5 & 4 & $14,29 \%$ & 2 & $9,09 \%$ & 6 & $12 \%$ \\
\hline
\end{tabular}




\begin{tabular}{|c|c|c|c|c|c|c|c|}
$\mathbf{5}$ & 4 & 3 & $10,71 \%$ & 1 & $4,55 \%$ & 4 & $8 \%$ \\
\hline $\mathbf{6}$ & 3 & 3 & $10,71 \%$ & 5 & $22,73 \%$ & 8 & $16 \%$ \\
\hline $\mathbf{7}$ & 2 & 7 & $25,00 \%$ & 6 & $27,27 \%$ & 13 & $26 \%$ \\
\hline $\mathbf{8}$ & 1 & 10 & $35,71 \%$ & 7 & $31,82 \%$ & 17 & $34 \%$ \\
\hline Total & & 28 & $100 \%$ & 22 & $100 \%$ & 50 & $100 \%$ \\
\hline
\end{tabular}

Berdasarkan tabel diatas tidak ada seorang pun (0\%) anak lakil-laki maupun anak perempuan yang melakukan permainan sebanyak yang melakukan permainan sebanayak 8 dan 7 buah permainan yang dilakukan disekolah setiap hari Terdapat 1 orang anak laki-laki $(3,57 \%)$ dan 1 orang anak perempuan $(4,55 \%)$ yang melakukan permainan sebanyak 6 buah permainan disekolah setiap hari dengan jumlah sebanyak 2 orang (4\%). Terdapat 4 orang anak laki-laki (14,29\%) dan 2 orang anak perempuan $(9,09 \%)$ yang melakukan permainan sebanyak 5 buah permainan diekolah setiap hari dengan jumlah sebanyak 6 orang (12\%). Terdapat 3 orang anak laki-laki (10,71\%) dan 1 orang anak perempuan (4,55\%) yang melakukan permainan sebanyak 4 buah permainan di sekolah setiap hari dengan jumlah sebanyak 4 orang (8\%). Terdapat 3 orang anak laki-laki $(10,71 \%)$ dan 5 orang anak perempuan $(22,73 \%)$ yang melakukan permainan sebanyak 3 buah permainan disekolah setiap hari dengan jumlah sebanyak 8 orang (16\%). Terdapat 7 orang anak laki-laki $(25,00 \%)$ dan 6 orang anak perempuan $(27,27 \%)$ yang melakukan permainan sebanyak 2 buah permainan disekolah setiap hari dengan jumlah sebanyak 13 orang (26\%). Terdapat 10 orang anak laki-laki $(35,71 \%)$ dan 7 orang anak perempuan (31,82\%) yang melakukan permainan sebanyak 1 buah permainan disekolah setiap hari dengan jumlah sebanyak 17 orang (34\%).

c. Lama Waktu Anak-Anak Melakukan Permainan di Luar Waktu Sekolah

Dari pertanyaan terbuka yang telah diwawancara kepada 50 orang peserta didik terlihat pada hasil analisis data lama waktu anak-anak melakukan permainan diluar waktu sekolah rerata tanpa membedakan jenis kelamin 1 jam setiap hari dengan persentase $52 \%$. Untuk lebih jelas dapat dilihat pada tabel dibawah.

Tabel 8. Lama Waktu Anak-Anak Melakukan Permainan di Luar Waktu Sekolah

\begin{tabular}{|c|c|c|c|c|c|c|c|}
\hline \multirow{2}{*}{ No } & $\begin{array}{c}\text { Lama } \\
\text { Waktu } \\
\text { Bermain }\end{array}$ & $\begin{array}{c}\text { Laki- } \\
\text { Laki }\end{array}$ & $\mathbf{\%}$ & Perempuan & J & \multirow{2}{*}{ Jumlah } & \multirow{2}{*}{} \\
\hline $\mathbf{1}$ & 6 & 0 & $0 \%$ & 0 & $0 \%$ & 0 & $0 \%$ \\
\hline $\mathbf{2}$ & 5 & 0 & $0 \%$ & 0 & $0 \%$ & 0 & $0 \%$ \\
\hline $\mathbf{3}$ & 4,5 & 0 & $0 \%$ & 0 & $0 \%$ & 0 & $0 \%$ \\
\hline $\mathbf{4}$ & 4 & 0 & $0 \%$ & 0 & $0 \%$ & 0 & $0 \%$ \\
\hline $\mathbf{5}$ & 3,5 & 0 & $0 \%$ & 0 & $0 \%$ & 0 & $0 \%$ \\
\hline $\mathbf{6}$ & 3 & 6 & $22,22 \%$ & 0 & $0 \%$ & 6 & $12 \%$ \\
\hline $\mathbf{7}$ & 2,5 & 0 & $0,00 \%$ & 0 & $0 \%$ & 0 & $0 \%$ \\
\hline $\mathbf{8}$ & 2 & 5 & $18,52 \%$ & 9 & $39,13 \%$ & 14 & $28 \%$ \\
\hline $\mathbf{9}$ & 1,5 & 0 & $0,00 \%$ & 1 & $4,35 \%$ & 1 & $2 \%$ \\
\hline $\mathbf{1 0}$ & 1 & 15 & $55,56 \%$ & 11 & $47,83 \%$ & 26 & $52 \%$ \\
\hline $\mathbf{1 1}$ & 0,5 & 1 & $3,70 \%$ & 2 & $8,70 \%$ & 3 & $6 \%$ \\
\hline Total & & 27 & $100 \%$ & 23 & $100 \%$ & 50 & $100 \%$ \\
\hline
\end{tabular}

Berdasarkan tabel diatas lama waktu melakukan permainan diluar waktu sekolah 6 jam, 5 jam, 4.5 jam, 4, dan 3.5 jam tidak ada seorang pun anak laki-laki (0\%) maupun anak perempuan. Terdapat 6 orang anak laki-laki $(22,22 \%)$ tidak terdapat anak perempuan $(0 \%)$ yang lama waktu melakukan permainan 3 jam di luar sekolah dengan jumlah sebanyak 6 orang (12\%). Tidak terdapat anak laki-laki $(0 \%)$ mapuan anak 
E-ISSN2655-2515

P-ISSN2655-1802

perempuan yang lama waktu 2.5 jam melakukan permainan di luar sekolah. Terdapat sebanyak 5 orang anak laki-laki $(18,52 \%)$ dan 9 orang anak perempuan $(39,13 \%)$ yang lama waktu melakukan permainan 2 jam diluar waktu sekolah setiap hari dengan jumlah sebanyak 14 orang $(28 \%)$. Tidak teradapat pada anak laki-laki $(0 \%)$ tetapi terdapat pada 1 orang anak perempuan $(4,35 \%)$ yang lama waktu 1.5 jam melakukan permainan di luar sekolah dengan jumlah 1 orang (2\%). Terdapat 15 orang anak laki-laki $(55,56 \%)$ dan 11 orang anak perempuan (47,83\%) lama waktu melakukan permainan 1 jam di luar sekolah dengan jumlah sebanyak 26 orang (52\%). Terdapat 1 orang anak laki-laki $(3,70 \%)$ dan 2 orang anak perempuan $(8,70 \%)$ lama waktu melakukan permainan 0.5 jam diluar sekolah dengan jumlah sebanyak 3 orang (6\%).

d. Lama Waktu Anak-Anak Melakukan Permainan di Sekolah

Dari pertanyaan terbuka yang telah diwawancara kepada 50 orang peserta didik dapat dilihat pada hasil analisis data lama waktu anak-anak melakukan permainan disekolah rerata tanpa membedakan jenis kelamin menjawab 0,5 (setengah jam) setiap hari. Dapat dilihat pada tabel dibawah.

Tabel 9. Lama Waktu Anak-Anak Melakukan Permainan di Sekolah

\begin{tabular}{|c|c|c|c|c|c|c|c|}
\hline \multirow[b]{2}{*}{ No } & \multirow{2}{*}{$\begin{array}{c}\text { Lama } \\
\text { Waktu } \\
\text { Bermain }\end{array}$} & \multicolumn{4}{|c|}{ Jenis Kelamin } & \multirow[b]{2}{*}{ Jumlah } & \multirow[b]{2}{*}{$\%$} \\
\hline & & $\begin{array}{l}\text { Laki- } \\
\text { Laki }\end{array}$ & $\%$ & Perempuan & $\%$ & & \\
\hline 1 & 3 & 0 & $0 \%$ & 0 & $0 \%$ & 0 & $0 \%$ \\
\hline 2 & 2,5 & 0 & $0 \%$ & 0 & $0 \%$ & 0 & $0 \%$ \\
\hline 3 & 2 & 1 & $4 \%$ & 9 & $36 \%$ & 10 & $20 \%$ \\
\hline 4 & 1,5 & 1 & $4 \%$ & 0 & $0 \%$ & 1 & $2 \%$ \\
\hline 5 & 1 & 11 & $44 \%$ & 7 & $28 \%$ & 18 & $36 \%$ \\
\hline 6 & 0,5 & 12 & $48 \%$ & 9 & $36 \%$ & 21 & $42 \%$ \\
\hline 7 & 20 & 0 & $0 \%$ & 0 & $0 \%$ & 0 & $0 \%$ \\
\hline 8 & 0,25 & 0 & $0 \%$ & 0 & $0 \%$ & 0 & $0 \%$ \\
\hline total & & 25 & $100 \%$ & 25 & $100 \%$ & 50 & $100 \%$ \\
\hline
\end{tabular}

Berdasarkan tabel diatas tidak ada seorang pun anak laki-laki $(0 \%)$ maupun anak perempuan yang lama waktu bermain dilakukan 3 jam dan 2.5 jam di sekolah. Terdapat 1 orang anak laki-laki (4\%) dan 9 orang anak perempuan (36\%) lama waktu melakukan permainan 2 jam disekolah setiap hari dengan jumlah sebanyak 10 orang (20\%). Terdapat 1 orang anak laki-laki (4\%) anak perempuan tidak terdapat (0\%) yang lama melakukan permainan 1.5 jam di sekolah dengan jumlah sebanyak 1 orang (2\%). Terdapat sebanyak 11 orang anak laki-laki (44\%) dan 7 anak perempuan (28\%) lama melakukan permainan 1 jam disekolah setiap hari dengan jumlah sebanyak 18 orang (36\%). Terdapat 12 orang anak laki-laki (48\%) dan 9 orang anak perempuan (36\%) lama melakukan permainan 0.5 jam disekolah setiap hari dengan jumlah sebanyak 21 orang $(42 \%)$. Tidak terdapat seorang pun baik anak laki-laki mapuan $(0 \%)$ anak perempuan yang lama waktu melakukan permain 20 menit dan 0.25 menit disekolah setiap hari.

e. $\quad$ Perhatian Orang Tua terhadap Kegiatan Bermain Anaknya

Dari pertanyaan terbuka yang telah diwawancara kepada 50 orang peserta didik dilihat dari hasil analisis data perhatian orang terhadap kegiatan bermain anak rerata tanpa membedakan jenis kelamin menjawab 46 orang mendukung dengan persentase $92 \%$.dengan syarat melarang main berlebihan, pekerjaan rumah telah selesai, tidak main jauh-jauh, dan melarang bermain dengan anak nakal. Dapat dilihat pada tabel di bawah. Tabel 10. Perhatian Orang Tua terhadap Kegiatan Bermain Anaknya 
E-ISSN2655-2515

P-ISSN2655-1802

\begin{tabular}{|c|c|c|c|c|c|c|c|}
\hline \multirow[b]{2}{*}{ No } & \multirow{2}{*}{$\begin{array}{l}\text { Perhatian } \\
\text { Orang Tua }\end{array}$} & \multicolumn{4}{|c|}{ Jenis Kelamin } & \multirow[b]{2}{*}{ Jumlah } & \multirow[b]{2}{*}{$\%$} \\
\hline & & $\begin{array}{l}\text { Laki- } \\
\text { Laki }\end{array}$ & $\%$ & Perempuan & $\%$ & & \\
\hline 1 & Mendukung & 25 & $86,21 \%$ & 21 & $100 \%$ & 46 & $92 \%$ \\
\hline 2 & $\begin{array}{c}\text { Tidak } \\
\text { Mendukung }\end{array}$ & 4 & $13,79 \%$ & 0 & $0 \%$ & 4 & $8 \%$ \\
\hline Total & & 29 & $100 \%$ & 21 & $100 \%$ & 50 & $100 \%$ \\
\hline
\end{tabular}

Berdasarkan tabel diatas terdapat 25 anak laki-laki (86,21\%) dan 21 anak perempuan $(100 \%)$ menyatakan orang tuanya mendukung terhadap kegiatan bermain dengan syarat melarang bermain jauh-jauh, tidak bermain dengan anak yang yang nakal, telah selsai mengerjakan pekerjaan rumah dengan jumlah sebanyak 46 orang $(92 \%)$. Kemudian terdapat 4 orang anak laki-laki (13,79\%) orang tuanya tidak mendukung terhadap kegiatan bermain dan pada anak perempuan tidak ada orang tua yang tidak mendukung kegiatan bermain dengan jumlah 4 orang $(8 \%)$ sebab orang tua tidak mendukung karena orang tua terlalu sibuk.

f. Alat Permainan yang Dipilih Anak-Anak dalam Melakukan Permainan

Dari pertanyaan terbuka yang telah diwawancara kepada 50 orang peserta didik terdapat dari hasil analisis data alat permainan yang dipilih anak-anak dalam melakukan permainan rerata tanpa membedakan jenis kelamin menjawab 37 orang lebih memilih memakai alat dengan persentase $74 \%$ alasan nya lebih menyenangkan dan lebih seru. Dapat dilihat pada tabel dibawah.

Tabel 11. Alat Permainan yang Dipilih Anak-Anak dalam Melakukan Permainan

\begin{tabular}{|c|c|c|c|c|c|c|c|}
\hline \multirow[b]{2}{*}{ No } & \multirow{2}{*}{$\begin{array}{c}\text { Alat } \\
\text { Permainan }\end{array}$} & \multicolumn{4}{|c|}{ Jenis Kelamin } & \multirow[b]{2}{*}{ Jumlah } & \multirow[b]{2}{*}{$\%$} \\
\hline & & $\begin{array}{l}\text { Laki- } \\
\text { Laki }\end{array}$ & $\%$ & Perempuan & $\%$ & & \\
\hline 1 & Pakai Alat & 22 & $75,86 \%$ & 15 & $71,43 \%$ & 37 & $74 \%$ \\
\hline 2 & Tanpa Alat & 7 & $24,14 \%$ & 6 & $28,57 \%$ & 13 & $26 \%$ \\
\hline Total & & 29 & $100 \%$ & 21 & $100 \%$ & 50 & $100 \%$ \\
\hline
\end{tabular}

Berdasarkan tabel diatas terdapat 22 orang anak laki-laki $(75,86 \%)$ dan 15 orang anak perempuan $(71,43 \%)$ yang memilih melakukan permainan memakai alat dengan jumlah sebanyak 37 orang $(74 \%)$ dengan alas an lebih seru, lebih menyenangkan lebih mudah dan tidak cepat membosankan. Terdapat 7 orang anak laki-laki $(24,14 \%)$ dan 6 orang anak perempuan $(28,57 \%)$ memilih melakukan permainan tanpa menggunakan alat dengan jumlah sebanyak 13 orang (26\%) dengan alasan lebih cepat, lebih senang lebih mudah, dan lebih irit biaya.

g. Tujuan Anak-Anak Melakukan Permainan

Dari pertanyaan terbuka yang telah diwawancara kepada 50 orang peserta didik pada hasil analisis data tujuan anak-anak melakukan permainan tanpa membedakan jenis kelamin yaitu lebih menonjolkan aspek psikomotor,aspek afektif, aspek sosial dengan alasan agar tubuh sehta, menyenangkan hati, menenangkan pikiran, menghilangkan jenuh, menghilangkan stress dan masala yang dihadapi, mengeluarkan keringat, menguatkan fisik, juga menyegarkan tubuh.

Tabel 12. Tujuan Anak-Anak Melakukan Permainan

\begin{tabular}{|c|l|c|c|c|}
\hline \multirow{2}{*}{ No } & \multicolumn{1}{|c|}{ Domain } & \multicolumn{2}{|c|}{ Frekuensi } & \multirow{2}{*}{} \\
\cline { 3 - 5 } & & $\begin{array}{c}\text { LAKI- } \\
\text { LAKI }\end{array}$ & PEREMPUAN & Jumlah \\
\hline $\mathbf{1}$ & Kognitif & & & \\
\hline & A. Menambah Wawasan Bermain & 0 & 0 & 0 \\
\hline
\end{tabular}


E-ISSN2655-2515

P-ISSN2655-1802

\begin{tabular}{|c|c|c|c|c|}
\hline & B. Menambah Ilmu & 0 & 0 & 0 \\
\hline & C. Melatih Pola Berpikir & 0 & 0 & 0 \\
\hline & D. Memahami Permainan & 0 & 0 & 0 \\
\hline & Total & 0 & 0 & 0 \\
\hline \multirow[t]{6}{*}{2} & Psikomotor & & & \\
\hline & $\sim$ Supaya Sehat & 9 & 8 & 17 \\
\hline & $\sim$ Menyegarkan Tubuh & 4 & 3 & 7 \\
\hline & $\sim$ Mengeluarkan Keringat & 1 & 3 & 4 \\
\hline & $\sim$ Melatih Fisik & 3 & 0 & 3 \\
\hline & Total & 17 & 14 & 31 \\
\hline \multirow[t]{8}{*}{3} & Afeksi & & & \\
\hline & $\sim$ Menghilangkan Kejenuhan & 1 & 4 & 5 \\
\hline & $\sim$ Hobi & 1 & 0 & 1 \\
\hline & $\sim$ Menghilangkan Masalah Yang Dihadapi & 5 & 0 & 5 \\
\hline & $\sim$ Menyenangkan Hati & 0 & 1 & 1 \\
\hline & $\sim$ Bergembira & 1 & 1 & 2 \\
\hline & $\sim$ Menambah Semangat & 1 & 0 & 1 \\
\hline & Total & 9 & 6 & 15 \\
\hline \multirow[t]{4}{*}{4} & Sosial & & & \\
\hline & $\sim$ Menambah Pergaulan & 1 & 1 & 2 \\
\hline & $\sim$ Menambah Keakraban & 1 & 1 & 2 \\
\hline & Total & 2 & 2 & 4 \\
\hline
\end{tabular}

Berdasarkan tabel diatas tidak terdapat anak laki-laki maupun anak perempuan (0\%)yang menyatakan tujuan bermain ditinjau dari domain kognitif dengan kategori menambah wawasan bermain, menambah ilmu pengetahuan, melatih pola pikir, dan menambah wawasan memahami permainan. Pada domain psikomotor terdapat : (a) supaya badan sehat 9 orang anak laki-laki dan 8 orang anak perempuan dengan jumlah 17 orang menyatakan tujuan melakukan permainan supaya badan sehat, (b) menyegarkan tubuh 4 orang anak laki-laki dan 3 orang anak perempuan dengan jumlah 7 orang menyatakan tujuan melakukan permainan, (c) mengeluarkan keringat 1 orang anak laki-lkai dan 3 orang anak perempuan menyatakan tujuan melakukan permainan supaya mengeluarkan keringat dengan jumlah 4 orang anak, (d) melatih fisik 3 orang anak laki-laki menyatakan tujuan bermain melatih fisik. Domain afeksi (a) menghilangkan kejenuhan 1 orang anak laki-laki dan 4 orang anak perempuan dengan jumlah 5 orang, (b) hobi 1 orang anak laki-laki tidak terdapat anak perempuan dengan jumlah 1 orang, (c) menghilangkan masalah yang dihadapi 5 orang anak laki-laki dan tidak terdapat anak perempuan menyatakan dengan jumlah 5 orang, (d) bergembira 1 orang anak laki-laki dan 1 orang anak perempuan dengan jumlah 2 orang, (d) menambah semangat 1 orang anak laki-laki dan tidak terdapat anak perempuan. Domain sosial (a) menambah pergaulan 1 orang anak laki-laki dan 1 orang anak perempuan dengan jumlah 2 orang , (b) menambah keakraban 1 orang laki-laki dan 1 orang anak perempuan dengan jumlah 2 orang.

h. Perasaan Anak Setelah Melakukan Permainan

Dari pertanyaan terbuka yang telah diwawancara kepada 50 orang peserta didik terdapat hasil analisis data perasaan anak setelah melakukan permainan rata-rata menjawab 18 orang lelah dengan persentase 36\% tanpa membedakan jenis kelamin. Dapat dilihat pada tabel dibawah. 
E-ISSN2655-2515

P-ISSN2655-1802

Tabel 13. Perasaan Anak Setelah Melakukan Permainan

\begin{tabular}{|c|c|c|c|c|c|c|c|}
\hline & & \multicolumn{3}{|c|}{ Frekuensi } & & \\
\cline { 3 - 6 } No & Domain & $\begin{array}{c}\text { Laki- } \\
\text { Laki }\end{array}$ & $\mathbf{\%}$ & Perempuan & \% & Jumlah & \% \\
\hline $\mathbf{1}$ & Senang & 5 & $17,86 \%$ & 9 & $40,91 \%$ & 14 & $28 \%$ \\
\hline $\mathbf{2}$ & Gembira & 5 & $17,86 \%$ & 4 & $18,18 \%$ & 9 & $18 \%$ \\
\hline $\mathbf{3}$ & Badan Terasa Sehat & 3 & $10,71 \%$ & 0 & $0,00 \%$ & 3 & $6 \%$ \\
\hline $\mathbf{4}$ & Lelah & 11 & $39,29 \%$ & 7 & $31,82 \%$ & 18 & $36 \%$ \\
\hline $\mathbf{5}$ & Bersemangat & 1 & $3,57 \%$ & 1 & $4,55 \%$ & 2 & $4 \%$ \\
\hline $\mathbf{6}$ & Segar & 3 & $10,71 \%$ & 1 & $4,55 \%$ & 4 & $8 \%$ \\
\hline & Total & 28 & $100 \%$ & 22 & $100 \%$ & 50 & $100 \%$ \\
\hline
\end{tabular}

Berdasarkan tabel diatas terdapat 5 orang anak laki-laki $(17,86 \%)$ dan 9 anak orang perempuan $(40,91 \%)$ menyatakan perasaan senang setelah melakukan permainan dengan jumlah 14 orang $(28 \%)$. terdapat 5 orang anak laki-laki $(17,86 \%)$ dan 4 orang anak perempuan (18,18\%) menyatakan perasaan gembira setelah melakukan permainan dengan jumlah 9 orang (18\%). Terdapat 3 orang anak laki-laki $(10,71 \%)$ meyatakan perasaan badan terasa sehat dan tidak seorangpun anak perempuan $(0 \%)$ dengan jumlah seluruh 3 orang (3\%). Terdapat 11 orang anak laki-laki $(39,29 \%)$ dan 7 orang anak perempuan $(31,82 \%)$ menyatakan perasaan lelah setelah melakukan permainan dengan jumlah 18 orang (36\%). Terdapat 1 orang anak laki-laki $(3,57 \%)$ dan 1 orang anak perempuan (4,55\%) menyatakan perasaan bersemangat setelah melakukan permainan dengan jumlah 2 orang (4\%). Terdapat 3 orang anak laki-laki $(10,71 \%)$ dan 1 orang anak perempuan $(4,55 \%)$ menyatakan perasaan segar setelah melakukan permainan dengan jumlah 4 orang $(8 \%)$.

i. Perasaan Anak Sewaktu Akan Melakukan Permainan

Dari pertanyaan terbuka yang telah diwawancara kepada 50 orang peserta didik terdapat pada hasil analisis data perasaan anak sewaktu melakukan permainan rerata menjawab 38 orang senang dengan persensate $76 \%$. Dapat dilihat pada tabel dibawah.

Tabel 14. Perasaan Anak Sewaktu Akan Melakukan Permainan

\begin{tabular}{|c|c|c|c|c|c|c|c|}
\hline & & \multicolumn{3}{|c|}{ Frekuensi } & & \\
\cline { 3 - 6 } No & Domain & Laki-Laki & $\mathbf{\%}$ & Perempuan & \% & Jumlah & \% \\
\hline $\mathbf{1}$ & Senang & 20 & $76,92 \%$ & 18 & $75,00 \%$ & 38 & $76 \%$ \\
\hline $\mathbf{2}$ & Bahagia & 0 & $0,00 \%$ & 0 & $0,00 \%$ & 0 & $0 \%$ \\
\hline & Badan Terasa & & & & & & \\
$\mathbf{3}$ & Sehat & 0 & $0,00 \%$ & 0 & $0,00 \%$ & 0 & $0 \%$ \\
\hline $\mathbf{4}$ & Lelah & 0 & $0,00 \%$ & 0 & $0,00 \%$ & 0 & $0 \%$ \\
\hline $\mathbf{5}$ & Bersemangat & 1 & $3,85 \%$ & 1 & $4,17 \%$ & 2 & $4 \%$ \\
\hline $\mathbf{6}$ & Gembira & 5 & $19,23 \%$ & 5 & $20,83 \%$ & 10 & $20 \%$ \\
\hline & Total & 26 & $100 \%$ & 24 & $100 \%$ & 50 & $100 \%$ \\
\hline
\end{tabular}

Berdasarkan tabel diatas 20 orang anak laki-laki (76,92\%) dan 18 orang anak perempuan $(75,00 \%)$ menyatakan perasaan senang sewaktu akan melakukan permainan dengan jumlah 38 orang $(76 \%)$. tidak terdapat satu orang pun anak laki-laki maupun anak perempuan yang menyatakan perasaan bahagia, lelah, dan badan sehat sewaktu akan melakukan permainan Terdapat 1 orang anak laki-laki $(3,85 \%)$ dan 1 orang anak perempuan (4,17\%) menyatakan perasaan bersemangat sewaktu akan melakukan permainan dengan jumlah 2 orang (4\%). Terdapat 5 orang anak laki-laki $(19,23 \%)$ dan 5 orang anak perempuan $(20,83 \%)$ menyatakan perasaan gembira sewaktu akan melakukan permainan dengan jumlah 10 orang (20\%). 
E-ISSN2655-2515

P-ISSN2655-1802

j. Tempat Bermain Yang Disenangi Oleh Anak

Dari pertanyaan terbuka yang telah diwawancara kepada 50 orang peserta didik te rdapat hasil analisis data tempat bermain yang disenangi oleh anak rerata memilih bermain diluar ruangan 46 orang tanpa membedakan jenis kelamin dengan persentase $92 \%$. Dengan alasan lebih bebas, dan lebih menyenangkan tidak mengganggu orang tua. Dapat dilihat pada tabel dibawah.

Tabel 15. Tempat Bermain Yang Disenangi Oleh Anak

\begin{tabular}{|c|c|c|c|c|c|c|c|}
\hline \multirow{2}{*}{ No } & \multirow{2}{*}{$\begin{array}{c}\text { Tempat } \\
\text { Bermain }\end{array}$} & $\begin{array}{c}\text { Laki- } \\
\text { Laki }\end{array}$ & $\boldsymbol{\%}$ & Perempuan & \% & \multirow{2}{*}{ Jumlah } & \multirow{2}{*}{} \\
\hline $\mathbf{1}$ & $\begin{array}{c}\text { Dalam } \\
\text { Ruangan }\end{array}$ & 2 & $7,14 \%$ & 2 & $9,09 \%$ & 4 & $8 \%$ \\
\hline $\mathbf{2}$ & Luar Ruangan & 26 & $92,86 \%$ & 20 & $90,91 \%$ & 46 & $92 \%$ \\
\hline Total & & 28 & $100 \%$ & 22 & $100 \%$ & 50 & $100 \%$ \\
\hline
\end{tabular}

Berdasarkan tabel diatas terdapat 2 anak laki-laki (7,14\%) dan 2 anak perempuan $(9,09 \%)$ memilih melakukan permainan didalam ruangan dengan jumlah semua 4 orang (8\%) dengan alasan lebih senang, lebih aman dan bisan menjaga adik di dalam rumah. Kemudian 26 orang anak laki-laki (92,86\%) dan 20 orang anak perempuan $(90,91 \%)$ memilih melakukan permainan di luar ruangan dengan jumlah keseluruhan 46 orang (92\%) alasannya lebih menyenangkan, lebih berkeringat dan banyak mengeluarkan tenaga, tidak mengganggu orang tua dan adik, dan lebih luas juga bebas.

\section{Pembahasan}

Berdasarkan hasil penelitian dapat disimpulkan, analisis mengenai aktivitas bermain peserta didik di tinjau dari aspek psikologis siswa sekolah dasar negeri 09 teluk bakung kecamatan bayang diperoleh rata-rata (mean) 101, skor minimal 76, skor maksimal 137, skor median (tengah) 99,5, nilai yang sering muncul (modus) 96 , standar deviasi (SD) 13,2 .

Aktivitas bermain adalah suatu kegitan yang memberikan kesegaran agar fisik dan kesenangan psikis melalui aktivitas fisik. Aktivitas bermian juga merupakan cara paling baik untuk mengembangkan kemampuan sesuai kompotisi anak melalui bermain anak memperoleh dan memproses evaluasi belajar hal-hal baru dan melatih melakukan keterampilan yang ada. Fungsi utama bermain adalah untuk merangsang perkembangan sensoris motorik, perkembangan intelektual, perkembangan sosial, perkembangan kreativitas, perkembangan kesadaran diri, perkembangan moral, dan bermain sebagai terapi.

Dalam Anton Komaini (2018:77) menurutnya ada beberapa manfaat bermain bagi perkembangan anak yaitu: (a) aspek fisik motorik, bila anak mendapat kesempatan untuk melakukan kegiatan yang banyak melibatkan aktivitas fisik terutama motorik kasar, akan membuat tubuh menjadi sehat, (b) permainan yang melibatkan keterampilan gerak dasar dan motorik halus akan meningkatkan keterampilan anak, (c) perkembangan kognitif. Saat bermain anak akan mengandalkan kemampuan bereksplorasi terhadap lingkungan melalui panca indranya, (d) Keterlibatan anak dengan orang lain dapat membantu anak untuk bersosialisasi dengan teman sebaya atau orang lain, (e) aspek perkembangan bahasa, melalui kegiatan bermain anak akan memperoleh kesempatan yang luas untuk berani berbicara, (f) aspek emosi dan kepribadian melalui bermain seorang anak dapat melepaskan ketegangan yang dialaminya. Selain itu anak akan dapat mengembangkan kemampuan berinteraksi dengan orang lain, peka, mau memantau dan dapat bekerja sama. kemampuan motorik baik sekali dan baik tentunya siswa yang terbiasanya melakukan aktivitas fisik, seperti aktivitas bermain, menjaga pola makan yang sehat, berolahraga dan sebagainya. Dari kebiasaan itu mereka dapatmemperkaya gerak motorik anak. Artinya anak adalah individu yang aktif dalam 
P-ISSN2655-1802

menerima hal- hal baru dilingkungan yang ada disekitarnya. Dapat disimpulkan anak yang memiliki kemampuan motorik baik adalah anak yang mudah melakukan berbagai gerakan yang diberikan oleh guru penjas disekolah tanpa ada merasa kesulitan sedikitpun.

Psikologi adalah ilmu yang mempelajari tingkah laku manusia atau ilmu yang mempelajari tentang gejala-gejala jiwa manusia. Menurut Yudrik Jahja (2012) Psikologi adalah ilmu yang mempelajari tingkah laku organisme yang hidup, terutama tingkah laku manusia. Bedasarkan definisi tersebut, maka psikologi dapat diartikan sebagai ilmu pengetahuan yang mempelajari dan mengkaji tingkah laku manusia dalam hubungan dengan lingkungan.

Hasil penelitian mengenai aktivitas bermain peserta didik ditinjau dari aspek psikologis siswa sekolah dasar negeri 09 teluk bakung kecamatan bayang dapat diklasifikasikan menyangkut domain perasaan senang, gembira, badan sehat, lelah, bersemangat, segar diuraikan sebagai berikut:

1. Perasaan anak sewaktu melakukan permainan

Berdasarkan hasil penelitian yang dilakukan menggunakan angket diketahui aktivitas bermain pesera didik ditinjau dari aspek psikologis siswa sekolah dasar negeri 09 teluk bakung kecamatan bayang terdapat 38 orang $(76 \%)$ menyatakan perasaan senang sewaktu melakukan permainan. Terdapat 0 orang $(0 \%)$ menyatakan perasaan bahagia sewaktu melakukan permainan. Terdapat 0 orang $(0 \%)$ menyatakan perasaan badan terasa sehat sewaktu melakukan permainan. Terdapat 0 orang $(0 \%)$ menyatakan perasaan lelah sewaktu akan melakukan permainan. Terdapat 2 orang (4\%) menyatakan perasaan bersemangat. Terdapat 10 orang (20\%) menyatakan perasaan gembira setelah melakukan permainan.

2. Perasaan anak setalah melakukan permainan

Berdasarkan hasil penelitian yang dilakukan menggunakan angket diketahui aktivitas bermain pesera didik ditinjau dari aspek psikologis siswa sekolah dasar negeri 09 teluk bakung kecamatan bayang terdapat 14 orang $(28 \%)$ menyatakan perasaan senang setelah melakukan permainan. Terdapat 9 orang $(18 \%)$ menyatakn perasaan gembira setelah melakukan permainan. Terdapat 3 orang $(6 \%)$ menyatakan perasaan badan terasa sehat. Terdapat 18 orang (36\%) menyatakan perasaan lelah. Terdapat 2 orang (4\%) menyatakan perasaan bersemangat. Terdapat 4 orang $(8 \%)$ menyatakan perasaan segar setelah melakukan permainan.

\section{Kesimpulan}

Berdasarkan hasil penelitian Aktivitas Bermain Peserta Didik Ditinjau Dari Aspek Psikologis Siswa SD Negeri 09 Teluk Bakung Kecematan Bayang Kabupaten Pesisir Selatan, maka dapat disimpulkan: terdapat 14 orang $(28 \%)$ menyatakan perasaan senang setelah melakukan permainan. Terdapat 9 orang (18\%) menyatakn perasaan gembira setelah melakukan permainan. Terdapat 3 orang $(6 \%)$ menyatakan perasaan badan terasa sehat. Terdapat 18 orang $(36 \%)$ menyatakan perasaan lelah. Terdapat 2 orang $(4 \%)$ menyatakan perasaan bersemangat. Terdapat 4 orang $(8 \%)$ menyatakan perasaan segar setelah melakukan permainan..

\section{Saran}

Sesuai kesimpulan hasil penelitian, maka dapat dikemukakan beberapa saran sebagai berikut :

1.Bagi guru disarankan memeberikan waktu untuk bermain pada siswa SDN 09 Teluk Bakung Kecamatan Bayang.

2.Bagi orang tua disarankan untuk mendukung kegiatan bermain pada anak diluar jam sekolah.

3.Bagi siswa disarankan mengobtimalkan waktu bermain disekolah maupun diluar jam sekolah. 


\section{Daftar Rujukan}

Giriwijoyo. 2007. Ilmu Faal Olahraga Fungsi Tubuh Manusia Pada Olahraga, Edisi 7, Bandung : Buku Ajar FPOK UPL.

Adriana, Dian. 2013. Tumbuh Kembang Dan Terapi Bermain Pada Anak. Jakarta: Salemba Medika.

Ahmadi,Abu dan Sholeh,Munawar. 2005. Psikologi Perkembangan. Jakarta: PT Asdi Mahasatya.

Ardiyanto, A. (2017). Bermain Sebagai Sarana Pengembangan Kreativitas Anak Usia Dini. Jendela Olahraga, 2(2), 35-39. https://doi.org/10.26877/jo.v2i2.1700

Ashar, M. (2018). Model Pembelajaran PJOK melalui Aktivitas Bermain untuk Membangun Karakter Peserta Didik Sekolah Dasar di Kabupaten Pasaman. JURNAL STAMINA, 1(1), 48-58.

Burhaein, E. (2017). Aktivitas Fisik Olahraga untuk Pertumbuhan dan Perkembangan Siswa SD. Indonesian Journal of Primary Education, 1(1), 51. https://doi.org/10.17509/ijpe.v1i1.7497

Desmita. 2009. Psikologi perkembangan peserta didik. Bandung: PT Remaja Rosdakarya.

Fisher, K. 2011. Playing Around in School Implication For Learning and Edocational policy. NY : Oxford University Press

Gusril. 2009. Perkembangan motorik pada masa anak-anak. Padang: UNP Press. .2017. Perkembangan motorik pada masa anak-anak. Padang: UNP Press. https://www.academia.edu/11694286/ASPEK_PSIKOLOGI_ANAK_DALAM_BELAJ AR

Jahja, Yudrik. 2012. Psikologi Perkembangan. Jakarta: Kencana Media Group.

Komaini, Anton. 2018 Kemampuan motorik anak usia dini. Depok: Rajawali Pers.

Latifa, U., \& Surakarta, I. (2017). Aspek Perkembangan pada Anak Sekolah Dasar: Masalah dan Perkembangannya. 1(2).

Prastowo, A., Studi, P., Guru, P., \& Ibtidaiyah, M. (2013). Kebutuhan Psikologis Dengan Tematik. Jurnal Pendidikan Sekolah Dasar, 1, 1-13.

Purwanto, Ngalim. 2007. Psikologi pendidikan. Jakarta: PT Remaja Rosdakarya.

Simatupang, N. (2005). Bermain sebagai upaya dini menanamkan aspek sosial bagi siswa sekolah dasar. Jurnal Pendidikan Jasmani Indonesia, 3(1).

Soetjiningsih, Hari Christiana. 2018. Perkembangan Anak. Depok: Prena Media Group.

Sumanto. 2014. Psikologi perkembangan. Yogyakarta: PT Buku Seru.

UU Nomor 20 tahun 2003. Tentang sistem pendidikan nasional. Jakarta: Depdiknas Upton, Penney. 2012. Psikologi Perkembangan. Jakarta: PT Gelora Aksara Pratama.

Yusuf, Syamsu. 2009. perkembangan peserta didik. Jakarta: PT Raja Grafindo Persada.Allen, K Eileen. 2010. Profil Perkembangan Anak. Jakarta. Erlangga 